\title{
The expansion of low-cost, state-subsidised childcare availability and mothers' return-to-work behaviour in East and West Germany
}

\author{
Gundula Zoch ${ }^{\text {a,c,** and Irina Hondralis }}$ b,c
}

[Accepted version published as: Zoch, Gundula; Hondralis, Irina (2017): The Expansion of Low-Cost, State-Subsidized Childcare Availability and Mothers' Return-to-Work Behaviour in East and West Germany. In: European Sociological Review 33 (5), S. 693-707. DOI: 10.1093/esr/jcx068.]

\begin{abstract}
:
This study investigates whether increased availability of low-cost, state-subsidised childcare for underthree-year-olds in Germany is associated with shorter employment interruptions amongst mothers. By focusing on a major childcare reform in East and West Germany, we examine the effect in two contexts that differ markedly in the acceptance and use of formal childcare and maternal employment. We combine rich longitudinal data from the German Socio-Economic Panel (2006 to 2014) with annual administrative county-level data on the availability of low-cost, state-subsidised childcare, estimating event history models. The results indicate that increased childcare availability for underthree-year-olds reduces mothers' employment interruptions, particularly after a second childbirth, and increases the probability of returning to part-time or full-time employment as opposed to marginal employment. Furthermore, increased availability of low-cost, state-subsidised childcare increases mothers' likelihood of returning to employment in the second year after childbirth, when paid leave entitlements expire and the availability of childcare becomes important. However, our results are only statistically significant for West German mothers and only after the birth of a second child. The study extends the literature on women's return-to-work behaviour by providing evidence on the mediumterm impact of family policy on the duration of mothers' employment interruptions.
\end{abstract}

Keywords: childcare, duration of employment interruption, early childhood education, family policy, maternal employment, social policy

\footnotetext{
${ }^{\text {a } U n i v e r s i t y ~ o f ~ B a m b e r g, ~ F e l d k i r c h e n s t r . ~ 21, ~} 96045$ Bamberg, Germany, gundula.zoch@lifbi.de.

${ }^{\mathrm{b}}$ Goethe-University Frankfurt, Theodor-W.-Adorno-Platz 6, 60323 Frankfurt am Main, Germany, Irina.hondralis@gmx.de

${ }^{\mathrm{c}}$ Both authors contributed equally to this work.

*Corresponding author. E-mail: gundula.zoch@lifbi.de
} 


\section{The expansion of low-cost, state-subsidised childcare availability and mothers' return-to-work behaviour in East and West Germany}

\section{INTRODUCTION}

Germany has a long history as a conservative welfare state with low maternal labour force participation (e.g., Hanel and Riphahn, 2012), long employment interruptions after childbirth (e.g., Ziefle and Gangl, 2014) and a substantial motherhood penalty (e.g., Gangl and Ziefle, 2009). Long job-protected parental leave periods with low compensation and low childcare availability have encouraged the traditional male-breadwinner model, particularly in West Germany. Even 26 years after reunification, Germany remains a divided country, with East German mothers returning to employment faster after childbirth and more often to full-time employment than West German mothers (e.g., Grunow and Müller, 2012; Hanel and Riphahn, 2012). These persistent East-West differences have been frequently explained with greater availability of low-cost, state-subsidised childcare for under-three-year-olds in East Germany (e.g., Grunow and Müller, 2012; Kreyenfeld and Geisler, 2006).

Since 2005, the German government has made immense public investments to increase childcare services for under-three-year-olds to encourage faster returns to full-time employment among East and West German mothers. However, to the best of our knowledge, no study to date has addressed the question whether increased availability of low-cost, statesubsidised childcare actually reduces mothers' employment interruptions after childbirth. Studying mothers' interruption durations and therein resulting return-to-work behaviour is important to understand persistent gender inequalities. Long family-related employment interruptions do not only result in a traditional division of labour and an immediate loss of income for women, but also tend to place mothers on lower career and income trajectories 
over their life-course, resulting in higher job insecurity and lower pension entitlements (e.g., Sigle-Rushton and Waldfogel, 2007).

We contribute to the literature on the effects of childcare availability, by focusing on a major public childcare reform in Germany and investigate whether increased availability of low-cost, state-subsidised childcare shortens mothers' employment interruptions after childbirth. We link rich individual and household panel information from the German SocioEconomic Panel (2006-2014) with annual administrative records on childcare availability on the county-level (Kreisebene) to exploit large temporal and regional variation in childcare availability across counties within and between East and West Germany. By estimating separate event history models for East and West Germany, we study how the childcare effect varies in two contexts that differ markedly in their initial levels of childcare availability and the acceptance of non-parental care and maternal employment.

\section{InSTITUTIONAL CONTEXT AND CHILDCARE EXPANSION}

Up to the mid-2000s, Germany provided long parental leave periods with low compensation and limited state-subsidised childcare availability for under-three-year-olds, particularly in West Germany. ${ }^{1}$ Together with joint taxation, family health insurance, and generous child benefits (Bach et al., 2011), this family policy setting encouraged especially West German mothers to take long career breaks of more than three years and to return most commonly to part-time employment (Frodermann, Müller and Abraham, 2013). Although recent parental leave reforms have particularly encouraged shorter employment interruptions among West German mothers (e.g., Bergemann and Riphahn, 2015; Ziefle and Gangl, 2014), East German mothers still return to work sooner, and more often in full-time employment. This strong labour market attachment is often described as the legacy of the former German Democratic Republic, where paid maternal leave periods were comparatively short and childcare was widely available (Rosenfeld, Trappe and Gornick, 2004). After the German 
reunification, childcare availability was reduced in East Germany; however, East-West disparities in childcare availability persisted. Hence, in early 2006, before the start of the childcare expansion, more than 30 per cent of all under-three-year-old children in East Germany attended low-cost, state-subsidised childcare, whereas in West Germany, counties seldom reached rates above 20 per cent (Federal Statistical Office, 2008).

In the mid-2000s, the government started to implement a major childcare expansion aiming to speed up mothers' returns to employment, particularly in West Germany. Although nationally funded, the reform is planned and implemented by the German federal states and county-level authorities. In 2005 and 2008, two federal laws were passed to increase countylevel availability of low-cost, state-subsidised childcare for under-three-year-olds to at least 35 per cent by 2013, including the legal right to childcare for all children aged one and older that went into effect in August 2013. ${ }^{2}$ In 2014, 52 per cent of under-three-year-olds in East Germany attended a childcare institution, compared to 27 percent in West Germany, where a childcare availability of more than 20 per cent became accessible only after 2009 . However, these averages mask great regional variation in the childcare ratio, ranging from 45 to 63 per cent in East Germany and from 14 to 47 per cent in West Germany (Strunz, 2015). ${ }^{3}$

Along with formal childcare, previous research shows that return to work behaviour is also closely linked to parental leave benefits. Since 2007, parents receive an income-related paid parental leave for a period of twelve months, which parents can divide between them and extend it to a total of 14 months if one partner takes at least two months. Parental leave is paid at 65-67 per cent of net earnings before childbirth (capped at 1,800 Euros) and parents are provided with a three-year job guarantee.

This description of the institutional context highlights how the interaction of various family policies and a lack of low-cost, state-subsidised childcare have long encouraged the malebreadwinner model, particularly in West Germany, whereas greater availability of low-cost, state-subsidised childcare prior to the reform seems to have effectively supported maternal 
employment among East German mothers. With the recent increase in childcare availability in West Germany and additional capacities implemented in East Germany, the questions remains whether this has led to shorter interruption durations.

\section{Previous Research}

So far, research has focused almost exclusively on the effect of formal childcare on maternal labour supply, as opposed to the interruption duration after childbirth, providing mixed results. International studies, exploiting exogenous quasi-experimental reform variation in childcare availability, can be summarised as follows: While some studies show positive employment effects (see Morrissey, 2017 for an overview), with some studies finding larger effects in countries where the childcare availability was low prior to an expansion (e.g, Brilli, Del Boca and Pronzato, 2016 on Italy), others find small or no significant effects (e.g., Havnes and Mogstad, 2011 on Norway; Lundin, Mörk and Öckert, 2008 on Sweden). These small or insignificant estimates are explained with heterogeneous reform effects or with substitution effects of households using low-cost, state-subsidised childcare instead of informal care or costly private formal care (e.g., Havnes and Mogstad, 2011).

To our knowledge, no study to date has addressed the question of whether the availability of low-cost, state-subsidised childcare is associated with shorter employment interruptions after childbirth. Germany, with its recent childcare expansion, provides an interesting case study to analyse this effect. International findings on the effects of other childcare expansions are not applicable, as Germany, in particular West Germany, had an unusually low level of both private and state-subsidised childcare prior to the reform. Also with regard to welfare or family policy regime typologies, Germany has become a unique exception, as it combines family policies which reinforce the traditional male-breadwinner model, such as joint taxation and family health insurance, with recent policies which support the dual-earner, dual-carer model, in particular, the parental leave and childcare policies (Schober, 2014). In sum, due to 
the division of Germany, East and West Germany provide the opportunity to investigate the effect of increased availability of low-cost, state-subsidised childcare in two contexts that differ remarkably in their pre-reform levels of childcare availability, maternal employment as well as cultural attitudes towards work and care for young children. The persistent East-West differences in maternal employment and employment interruption durations have been frequently explained by greater childcare availability in the East (e.g., Grunow and Müller, 2012). However, no study to date has applied administrative childcare data to systematically analyse whether the gap in childcare availability between East and West Germany is responsible for the East-West difference in maternal employment and employment interruption durations. Pre-reform studies show no statistically significant association between childcare availability and maternal employment (Büchel and Spieß, 2002; Kreyenfeld and Hank, 2000). These cross-sectional studies, however, focus exclusively on the unusually low level of childcare in West Germany and were unable to consider substantial changes in childcare availability over time, which may explain the non-significant effects.

To date, the few post-reform studies provide mixed evidence on the effects of the recent childcare expansion in Germany. However, they again concentrate on maternal labour supply instead of on employment interruption durations after childbirth, without focusing on EastWest differences. Micro-simulations predict the childcare expansion (Haan and Wrohlich, 2011; Bonin et al., 2013) and the legal entitlement to a childcare slot for all children aged one year or older (Müller and Wrohlich, 2016) to increase maternal employment. Applying a quasi-experimental design, Geyer, Haan and Wrohlich (2015) show a positive effect on maternal labour supply, particularly among mothers with children aged two to three years, confirming the micro-simulations. In contrast, while distinguishing between East and West Germany, but using only a cross-sectional research design, Schober and Spiess (2015) do not find a statistically significant effect of childcare availability on maternal labour supply once they control for childcare quality. 
Our study adds to the current field of research by investigating the effect of an increased availability of low-cost, state-subsidised childcare on the length of East and West German mothers' employment interruption durations. We exploit the annual and regional variation in county-level administrative childcare and survey data, measuring actual employment behaviour instead of relying on simulation models. Additionally, we investigate whether the effect differs after the birth of a first or a second child and whether the effect is more pronounced when the paid parental leave benefits expire and the opportunity costs of employment increase in the second year after childbirth, as suggested by previous studies (Haan and Wrohlich, 2011; Geyer, Haan and Wrohlich, 2015). Furthermore, we assess whether increased availability of low-cost, state-subsidised childcare alters the likelihood of returning to more substantial (full-time or part-time) employment compared to marginal employment (so-called 'mini-jobs'), which is defined by a maximum monthly income of 400 Euro (after 2013, 450 Euros) and no social insurance contributions for employees.

\section{THEORETICAL FrAMEWORK}

Based on both economic and sociological theories, we assume that increased availability of low-cost, state-subsidised childcare shortens mothers' employment interruptions and facilitates faster returns to more substantial employment.

Overall, economic theory predicts shorter employment interruptions whenever low-cost, state-subsidised childcare availability for very young children is comparatively high (e.g., Kreyenfeld and Hank, 2000; Morrissey, 2017). According to the neoclassical theory of labour supply, mothers rationally decide when to return to work after giving birth in order to maximise lifetime income as well as household utility by considering their time requirements at home, market wages as well as alternative income sources such as household income (Blau, Ferber and Winkler, 2006). Low-cost, state-subsidised childcare reduces the opportunity costs for a return to work and allows mothers living in counties with greater availability to rely 
more on childcare than in counties with lower availability (for a more in-depth discussion, see Leibowitz, Klerman and Waite, 1992). In this theory, mothers who are indifferent about taking care of a child at home instead of enrolling the child in childcare will return to employment faster in a county with increased childcare availability than mothers who live in counties with lower availability. Beyond this, mothers might also decide based on the expectation that employers consider the duration of the interruption a signal of their productivity and work commitment (Spence, 1973). With widely available low-cost, statesubsidised childcare more mothers have the possibility to return to work faster and to thereby signal higher work commitment to employers.

Similarly, sociological theory suggests that formal childcare has the potential to reduce inter-role conflicts for working mothers (Greenhaus and Beutell, 1985). Particularly for workoriented mothers with young children, the combination of the role as a caregiver and worker is likely to result in interfering role demands. By allowing mothers to transfer some of their care responsibilities to a childcare institution, childcare potentially decreases the inter-role conflict and this might reduce mothers' employment interruptions.

Furthermore, constructivist identity approaches (Stets and Burke, 2000) describe the cultural construction of the ideal mother and worker associated with the individual opportunity structures and family policies (e.g., Banaszak, 2006; Sjöberg, 2004). Family policy reforms, such as shorter parental leave periods (Gangl and Ziefle, 2015) and increased availability of low-cost, state-subsidised childcare (Zoch and Schober, 2017) have been found to increase the cultural acceptance of maternal employment. Hence, mothers, who would have wanted to return to employment but felt constraint by traditional gender role ideologies, might be more likely to shorten their employment interruption, particularly in a comparatively traditional context, such as West Germany.

To summarise, both economic and sociological theories assume that the expansion of statesubsidised childcare for under-three-year-olds leads to shorter employment interruptions after 
childbirth. Based on these theories, we expect mothers to return to employment earlier in counties with more childcare available for under-three-year-olds (H1).

The economic labour supply theory also allows us to make a clear prediction of when the effect of childcare on mothers' return-to-work decisions is strongest. When paid parental leave entitlements expire in the second year of the child's life, the utility of staying at home declines and a negative income effect can be expected. Thereupon mothers heavily rely on childcare in order to return to work, which makes childcare availability particularly important. We therefore expect that increased availability of low-cost, state-subsidised childcare does not affect the probability of returning equally but is strongest in the second year after childbirth (H2).

Increasing childcare availability also allows mothers to work longer hours, as it becomes more accessible for mother to take-up childcare during specific hours, compared to informal caring arrangements, which are only available to few and for a few hours a day. We therefore expect mothers in counties with increased availability of low-cost, state-subsidised childcare to be more likely to work longer hours and, hence, to return to substantial employment, such as full-time or part-time work, compared to mothers living in counties with childcare rationing to return to marginal employment $(\mathrm{H} 3)$.

Due to a long history of East-West differences in the take-up of formal childcare and the acceptance of maternal employment, we expect the expansion of childcare availability to have heterogeneous effects on East and West German mothers. In East Germany using formal childcare for children older than one year, has been and still is the dominant social norm, whilst in West Germany, family care still prevails. These differences are also reflected in the more conservative attitudes towards maternal employment and formal childcare in West Germany, compared to East Germany. In 2012, only 13 per cent of East German women agreed with the statement that a child under six is likely to suffer from a working mother compared to 32 per cent of women in West Germany. With respect to childcare, only 17 per 
cent of East German mothers stated that care for under-six-year-olds should be provided by the family, whereas still 42 per cent of West German mothers agreed with the statement (Schober and Stahl, 2014). We therefore expect the effect of increased availability of lowcost, state-subsidised childcare on maternal employment returns to vary with cultural acceptance of formal childcare and of maternal employment, however, it is difficult to predict a priori for whom the effect will be more pronounced. On the one hand, an increased childcare availability in a region with a high acceptance of maternal employment and formal childcare take-up, such as East Germany, should encourage mothers to further decrease their employment interruptions (H4A). On the other hand, East Germany started expanding childcare at a higher level of availability, and returns to employment among mothers were already relatively fast; hence, there might exist a certain saturation effect with regard to faster returns to employment. Alternatively, increased availability of low-cost, state-subsidised childcare might have a stronger impact on the duration of employment interruptions among mothers in West Germany, where there is greater potential to shorten employment interruptions due to comparatively long interruption durations prior to the childcare expansion (H4B).

\section{RESEARCH DESIGN}

\section{Data Description}

To investigate whether increased availability of low-cost, state-subsidised childcare is associated with shorter employment interruptions among East and West German mothers, we combine annual administrative records on childcare availability on the county-level (Kreisebene) from the Federal Statistical Office with individual-level data from the representative German Socio-Economic Panel (SOEP) (Wagner, Frick and Schupp 2007). We use yearly individual and household information and monthly employment histories on East 
and West German mothers, with a first, second or any higher-order birth between January 2006 and December 2014.

Childcare availability is defined as the annual ratio of under-three-year-olds enrolled in subsidised childcare to the population of this age group, including half-day or full-day childcare centres or child-minders. ${ }^{4}$ Combining administrative county-level data with individual longitudinal information provides a unique opportunity to exploit, first, temporal variation from the years 2006 to 2014, second, regional variation between East and West Germany, and last, county-level variation in childcare availability from several counties in East and West Germany.

Figure 1 and 2 depicts the gradual increase in low-cost, state-subsidised childcare for under-three-year-olds over time and the variation around the mean in the East and West German counties observed in our sample. We observe mothers in counties, where the average childcare availability for under-three-year-olds increased from 7 to 27 per cent in West Germany and from 40 to 50 per cent in East Germany between 2006 and 2014. For West Germany, county-level childcare availability of more than 20 per cent is only observable after 2009 (see Online Appendix Table A1). These changes are comparable to official data on the increase in childcare availability in all counties across Germany. In the analysis, we utilise a categorical specification of childcare availability. Beyond this, we test linear, spline, u-shaped as well as different categorical childcare specifications (available on request), however, results presented are based on the most robust categorisation.

\section{- Figure 1 and 2 here -}

\section{Method of Analysis}

To estimate the probability of returning to employment conditional on not having returned to work yet and due to the discrete character of the data, we apply discrete event history analysis (Allison, 1982). More precisely, the piecewise-exponential model allows flexible modelling of the duration dependency of the baseline hazard and is better suited to handle right-censored 
observations in the data. Due to the relatively small number of events and a peak in the baseline hazard after 12 months (i.e. expiry of benefit payment), 24 months or 36 months (i.e. expiry of job guarantee), we present models using yearly intervals. However, results are comparable with monthly or half-year intervals.

Our risk set includes all mothers who gave birth, until we observe a return to the labour market (assigning an interruption of eight weeks to all, whilst employment is legally prohibited), another birth or the observation is censored. One of the model's assumptions is that the time of censoring is independent of the event. We define our dependent variable as a return to employment whenever the respondent states being employed marginal, part-time or full-time. To take the differing initial availability of state-subsidised childcare into account, we estimate separate models for East and West Germany. In a first step, we estimate the probability of a return to work for all births jointly, which includes first, second and higherorder births (Table 3, M1-M2). In a second step, to identify whether increased childcare availability has had different impacts on a mother's employment interruption after a first or a second birth, we split our samples into returns after a first or a second birth for East and West German mothers, respectively (Table 3, M3-M6). Since we observe very few mothers with a higher-order birth, we are unable to analyse these interruptions separately. In a third step, we examine whether increased childcare availability has a more pronounced effect on mothers' return-to-work decisions in the second year after childbirth, when income-related parental leave benefits expire (Figure 3 and 4). In a fourth and final step, we test, using a competing risks model, whether childcare encourages mothers to return to more substantial forms of employment, that is, full-time or part-time employment, as opposed to marginal employment (Table 4). ${ }^{5}$

We restrict our sample to mothers who gave birth between 2006 and 2014, as annual official childcare data has only been collected since the start of the childcare expansion in 2006. We exclude women who moved between counties during our observation period to 
avoid selective moving due to higher childcare availability in some counties, as well as the oversampled subsamples such as the high-income sample and migration samples. ${ }^{6}$ Following common practice, we right-censor observation periods after 6 years if no return is observed. Similarly, we right-censor spells that end with a birth of another child and instead let another observation period begin.

In total, we observe mothers in 287 of the 402 counties in Germany, 59 of which are located in East Germany. Based on all restrictions, our sample includes 1,016 episodes of 860 West German mothers for whom we observe 553 events. For East Germany, we observe 256 episodes of 219 mothers for whom we observe 166 events. 463 episodes of West German mothers (58 due to another birth) and 90 of East German mothers (12 due to another birth) are right-censored. The most censoring occurred due to missing information, non-response or a limited observation period (women with a birth at the end of the observation window are more often censored).

\section{Control Variables}

We control for the following relevant time-constant individual characteristics observed for the mother prior to childbirth: age, education and migration background, and time-constant prebirth employment characteristics, i.e. employment status (full-time, part-time or not employed) and the pre-birth hourly log wage adjusted for inflation (in 2011 Euros). We also include several time-varying control variables: family status (single, cohabitation and marriage), number of children in the household, if the child was born after the introduction of the new income-related parental leave benefit scheme in 2007 and log household income adjusted to inflation (in 2011 Euros).

To capture aspects of the regional economic situation that might influence maternal employment participation, we include the centred unemployment rate and female labour force participation rate on the county-level, provided annually by the Federal Statistical Office. In 
addition, we include the number of marriages per 1000 adult inhabitants, as a proxy for cultural differences between rural and urban areas and as an indicator for the importance of traditional family norms. To control for further unobserved influences, we included period dummies in all models. Table 1 and 2 present the distribution of the control variables for West and East Germany.

- Table $1 \& 2$ here -

\section{RESULTS}

\section{Childcare availability and interruption durations}

We utilise a categorical specification of childcare availability. For West Germany, we differentiate among availability of less than 15 per cent (reference category), between 15 and 22 per cent, and more than 23 per cent. For East Germany, the categories are less than 42 per cent (reference category), between 42 and 49 per cent, and more than 50 per cent. This categorisation allows for an approximately equal distribution of the changing childcare availability over the observation period (see Online Appendix Table A1). At the start of the observation period in West Germany regional availability of low-cost, state-subsidised childcare of less than 15 per cent is most common. Capacities of more than 23 per cent are only available after 2009. For East Germany, increased availabilities also become more common over our observation period.

We present results for East and West German mothers' return-to-work behaviour after any birth in Table 3 (M1 and M2), reporting average marginal effects. Our results show that increased childcare availability shortens the duration of employment interruptions among West German mothers and increases their probability of returning to employment. In actual terms, this means that when the childcare availability in a West Germany county reaches 15 per cent or more but remains below 23 per cent compared to the reference category, the probability of returning to work increases by one percentage point in any month after birth 
(M1). Similarly, when childcare is available to more than 23 per cent of all under-three-yearold children in a county, the probability of returning to work increases by two percentage points in any month after birth (M1). This implies that substantially greater childcare availability is responsible for faster returns to employment in West Germany. When individual and regional confounders are included (M2), the childcare coefficients are reduced, but still statistically significant. Although effect sizes are small, coefficients are generally comparable to individual and household controls (Online Appendix Table A2 and A3). The effects of these controls are in line with theoretical considerations and do not contradict other related studies. For East Germany, the effect of increased availability of low-cost, statesubsidised childcare is positive but statistically insignificant. Overall, this result provides support for our hypothesis $\mathrm{H} 1$ that an increased childcare availability reduces mothers' employment interruptions following childbirth, but only among West German mothers. Furthermore, although the East German sample is comparatively small, the results provide tentative evidence for our hypothesis H4B, which posits a higher potential for West German mothers to shorten their employment interruptions.

\section{Return-to-work behaviour after first and second childbirth}

When turning to the separate estimates for the employment interruption durations after a first or a second birth in Table 3 (M3-M6), it again becomes evident that considerable childcare ratio of above $23 \%$ is particularly important for West German mothers, especially after a second childbirth (M5-M6). For first births, estimates are positive but statistically insignificant, once we include individual and regional controls (M3-M4). This may suggests that West German mothers might perceive it as less beneficial to return to employment temporarily before having a second child. Again, for the much smaller sample of East German mothers, we find a positive although statistically insignificant effect. 


\section{Time-dependency of childcare availability on the duration of employment interruptions}

To test, whether the effect of increased childcare availability is similar at each point during the employment interruption $(\mathrm{H} 2)$, we interact the childcare measure with the time periods. We provide a graphical demonstration of our results only (full models are available on request). Figure 3 and 4 illustrate how different levels of childcare availability cause the predicted probability of returning to work to vary in the first year (0-11 months), second year (12-23 months), and beyond the third year (24 months and longer) after childbirth for both West and East German mothers. Including a time-dependent effect of childcare availability in the model indicates that childcare availability of more than 23 per cent increases West German mothers' probability of returning to employment in the second year after childbirth (Likelihood-Ration test: Chi-value 10.61, $\mathrm{p}=0.005$ ), providing support for $\mathrm{H} 2$. The timedependency effect is neither statistically significant for the first year after childbirth nor for the third year and beyond (coefficients not shown). Once more, for the smaller sample of East German mothers, we do not find a statistically significant effect.

\section{- Figure 3 and 4 here -}

\section{Returns to substantial versus marginal employment}

In a last step, we focus on the transition to full- and part-time employment, which we refer to as substantial employment, compared to a transition to marginal employment. Table 4 (M1 and M2) shows again a small and positive effect of increased childcare availability on the probability of returning to substantial employment only for West German mothers (full models in Online Appendix Table A4 and A5). The likelihood to return to marginal employment remains unaltered (M3 and M4). The childcare coefficients are of similar 
magnitude as in Table 3. The finding provides support for our initial assumption (H3) that increased childcare availability strengthens mothers' labour market attachment, since they return faster and work more hours, particularly for West German mothers.

\section{- Table 4 here -}

\section{Sensitivity checks}

We run several sensitivity checks that reinforce our findings. First, we include the child's month of birth in our models to control for increased availability of low-cost, state-subsidised childcare at beginning of the new school year in late August and early September. Second, we add different measures of mothers' work commitment to our models to ensure that our results are not driven by women with a stronger work or career orientation returning to work faster. Third, we re-estimated all models, without including the county-level marriage rate per 1000 adults to assess whether this control variable is driving our results. Fourth, we exclude births prior to the introduction of the shortened and income-related parental leave in 2007 to examine whether returns to work are driven by the new parental leave scheme. Similarly, we re-estimate all models excluding mothers with a child aged older than one year in August 2013 (144 mothers in West and 23 mothers in East Germany), to ensure that results were not driven by the introduction of the legal entitlement to a childcare place. In the same vein, we exclude the three states from our analysis that implemented a legal entitlement to childcare prior to 2013 (Rhineland Palatinate, Thuringia and Saxony Anhalt). Last, we test for the possibility of selective panel attrition. However, all sensitivity analyses show similar patterns and therefore confirm our previous findings (available on request).

\section{SUMMARY AND CONCLUSION}

Focusing on a major public childcare expansion in Germany, this study provides first evidence that an increased availability of low-cost, state-subsidised childcare for under-three- 
year-olds shortens mothers' employment interruptions after childbirth. By exploiting exogenous temporal and regional variation in county-level childcare availability in East and West Germany, we find that increased availability of low-cost, state-subsidised childcare significantly shortens employment interruptions among West German mothers. As the prereform availability and acceptance of formal childcare and maternal employment were low and interruption durations were comparatively long, West German mothers had a significant potential to shorten their interruption duration. For the much smaller East German sample, we find a positive but statistically insignificant effect. The findings for East and West German mothers suggest that an expansion of low-cost, state-subsidised childcare is more likely to significantly reduce the interruption duration after childbirth in a relatively traditional context with previously exceptionally low childcare availability. In contrast, due to the already comparatively short interruptions prior to the expansion, the potential for even shorter interruptions may have been limited among East German mothers. Hence, our results lend support to previous studies, which either find a small or no employment effect of statesubsidised childcare expansions when pre-reform childcare availability is comparatively welldeveloped (e.g., Brilli, Del Boca and Pronzato, 2016; Havnes and Mogstad, 2011; Lundin, Mörk and Öckert, 2008). However, it is important to keep in mind that we base these findings on a relatively small sample of East German mothers.

Beyond this, our findings suggest that the effect of increased availability of low-cost, statesubsidised childcare may be particularly pronounced for interruptions following a second birth. This might suggest that increased childcare availability does not significantly alter mothers' return-to-work behaviour if they still plan to have more children. Previous research supports this argument, showing that West German mothers have a tight spacing of two to four years between a first and second child (Kreyenfeld, 2008). It seems plausible that West German mothers, who plan to have a second child, perceive it as difficult to find short-term care arrangements for their first child and expect employers to be averse to a temporary return 
to employment. Hence, they may perceive a temporary return to work as less beneficial than a single but longer employment interruption. Therefore, formal childcare might become particularly important for faster labour market returns after family planning is likely to have been completed.

Furthermore, in line with previous research (Geyer, Haan and Wrohlich, 2015; Haan and Wrohlich, 2011) our results provide additional support that increased availability of low-cost, state-subsidised childcare increases mothers' likelihood of returning to employment in the second year after childbirth when paid leave entitlements expire and childcare becomes important. The design of the parental leave scheme can serve as an additional explanation for why increased childcare availability may increase the likelihood of returning to employment in the second year particularly among West German mothers, compared to East German mothers. The nature of the paid parental leave entitlement does not make it necessarily beneficial to have interruption durations below 12 months and to return to work whilst still entitled to paid leave, as paid leave entitlements are reduced by labour income. This finding provides tentative evidence that the effect of increased availability of low-cost, statesubsidised childcare depends on other family policies, in particular the income-related parental leave entitlement. Future research should evaluate how childcare availability interacts with other policies, which foster the male-breadwinner model and whether heterogeneous policy effects exist among various social groups and labour market contexts.

Finally, our findings suggest that increased availability of low-cost, state-subsidised childcare plays a significant role in supporting mothers' returns to substantial employment (again only statistically significant for West German mothers), whereas the effect of childcare availability on returns to marginal employment remains unaltered. Differentiating between mothers with different employment histories and investigating whether more full-time childcare slots will lead to more full-time employment, particularly in West Germany, should be examined in further research. 
A major limitation of our study is the small sample sizes, especially for East Germany, which did not allow for further subsample analyses. By exploiting temporal and regional variation in county-level childcare availability and a wide range of individual, household and county-level controls, we try to account for unobserved heterogeneity. Yet, the risk of biased estimates remains due to other unobserved characteristics, such as formal childcare quality, which may correlate with the childcare expansion and maternal employment. Despite these limitations our findings align with previous studies highlighting the importance of formal childcare for maternal employment (Morrissey, 2017 for an overview) and provide additional evidence of how family policy reforms, in our case the increased county-level availability of low-cost, state-subsidised childcare, significantly encourages reductions in employment interruptions and enables mothers to return to more substantial employment (part-time or full-time). In the future, research may observe a larger impact on maternal employment as full-time childcare slots are increasingly becoming available due to the legal entitlement to childcare. From a general perspective, our findings emphasise that an institutional change, which strengthens the dual-earner model, profoundly impacts on mothers' employment trajectories.

\section{NoTES}

1 Despite the lack of state-subsidised childcare availability for under-three-year-olds in West Germany, incentives for private providers were low due to high-quality requirements and no or limited subsidies. As a result, up to 2006 less than 2 per cent of children attended for-profit providers (Spieß, Berger and Groh-Samberg, 2008) and less than 5 per cent used informal paid care such as nannies or au-pairs (Schober, 2014). 
2 To date the legal right is not easily enforceable, as only few parents have taken legal action against regional authorities and these cases are still unsettled. In principle in 2016 the top court decided that employed parents are entitled to financial compensation (Financial Times, 2016). However, with only few observations available after August 2013, this paper focuses on the gradual expansion of childcare availability.

3 In light of the limited but state-subsidised childcare in Germany, it appears to be the availability rather than the cost of childcare that matters (Kreyenfeld and Hank, 2000). Since state subsidies cover approximately 85 per cent of the costs per slot, parents only pay an income-dependent fee of approximately 14 per cent of the total costs, which is well below the OECD average (Schober, 2014).

4 Despite the substantial increase in childcare availability, demand still exceeds the supply in East and West Germany (BMFSFJ, 2015). As this is constantly monitored, the childcare attendance rate is considered as a measure of supply rather than demand, which is in line with previous studies on Germany (for a detailed description, see Kreyenfeld and Hank, 2000).

5 Unfortunately, full-time returns are rarely observed, particularly in West Germany. Therefore, we define our dependent variable as a substantial return whenever the respondent states either being employed part-time or full-time.

$6 \mathrm{We}$ also run estimates across all the SOEP samples. Although results are comparable, we present more conservative estimates based on representative samples. 


\section{REFERENCES}

Allison, P. D. (1982). Discrete-Time Methods for the Analysis of Event Histories. Sociological Methodology, 13, 61-98.

Bach, S., Geyer, J., Haan, P. and Wrohlich, K. (2011). Reform of income splitting for married couples: Only individual taxation significantly increases working incentives. DIW Economic Bulletin, 1, 13-19.

Banaszak, L. A. (2006). The Gendering State and Citizens' Attitudes toward Women's Roles. State Policy, Employment, and Religion in Germany. Politics \& Gender, 2, 29-55.

Bergemann and Riphahn (2015). Maternal Employment Effects of Paid Parental Leave. IZA Discussion Paper 9073.

Blau, F. D., Ferber, M. A. and Winkler, A. E. (2006). The economics of women, men, and work. Upper Saddle River, NJ: Pearson/Prentice Hall.

Bonin, H., Fichtl, A., Rainer, H., Spieß, C. K., Stichnoth, H. and Wrohlich, K. (2013). Lehren für die Familienpolitik - Zentrale Resultate der Gesamtevaluation familienbezogener Leistungen. ifo Schnelldienst, 66, 22-30.

Brilli, Y., Del Boca, D. and Pronzato, C. D. (2016). Does child care availability play a role in maternal employment and children's development? Evidence from Italy. Review of Economics of the Household, 14, 27-51.

Büchel, F. and Spieß, C. K. (2002). Kindertageseinrichtungen und Müttererwerbstätigkeit Neue Ergebnisse zu einem bekannten Zusammenhang. Vierteljahrshefte zur Wirtschaftsforschung, 71, 95-113.

Bundesministerium für Familie, Senioren and Frauen und Jugend (2015). Fünfter Bericht zur Evaluation des Kinderförderungsgesetzes. Berlin.

Federal Statistical Office (2008). Kindertagesbetreuung regional 2007. Ein Vergleich aller 439 Kreise in Deutschland. Wiesbaden.

Financial Times (2016). German parents win compensation over childcare. Financial Times, Online October 21, 2016.

Frodermann, C., Müller, D. and Abraham, M. (2013). Determinanten des Wiedereinstiegs von Müttern in den Arbeitsmarkt in Vollzeit oder Teilzeit. Kölner Zeitschrift für Soziologie und Sozialpsychologie, 65, 645-668.

Gangl, M. and Ziefle, A. (2009). Motherhood, labor force behavior, and women's careers: an empirical assessment of the wage penalty for motherhood in Britain, Germany, and the United States. Demography, 46, 341-369.

Gangl, M. and Ziefle, A. (2015). The Making of a Good Woman. Extended Parental Leave Entitlements and Mothers' Work Commitment in Germany. American Journal of Sociology, 121, 511-563.

Geyer, J., Haan, P. and Wrohlich, K. (2015). The effects of family policy on maternal labor supply. Combining evidence from a structural model and a quasi-experimental approach. Labour Economics, 36, 84-98. 
Greenhaus, J. H. and Beutell, N. J. (1985). Sources of Conflict Between Work and Family Roles. Academy of Management Review, 10, 76-88.

Grunow, D. and Müller, D. (2012). Kulturelle und strukturelle Faktoren bei der Rückkehr in den Beruf: ostdeutsche, westdeutsche und ost-west-mobile Mütter im Vergleich. Zeitschrift für Familienforschung. Special Issue, 55-78.

Haan, P. and Wrohlich, K. (2011). Can child care policy encourage employment and fertility? Labour Economics, 18, 498-512.

Hanel, B. and Riphahn, R. T. (2012). The Employment of Mothers - Recent Developments and their Determinants in East and West Germany. Jahrbücher für Nationalökonomie und Statistik, 232.

Havnes, T. and Mogstad, M. (2011). Money for nothing? Universal child care and maternal employment. Journal of Public Economics, 95, 1455-1465.

Kreyenfeld, M. (2008). Das zweite Kind in Ostdeutschland: Aufschub oder Verzicht? In Cassens, I., Luy, M. and Scholz, R. (Eds.). Die Bevölkerung in Ost-und Westdeutschland: Demografische, gesellschaftliche und wirtschaftliche Entwicklungen seit der Wende. Wiesbaden: VS Verlag, pp. 100-123.

Kreyenfeld, M. and Geisler, E. (2006). Müttererwerbstätigkeit in Ost- und Westdeutschland. Eine Analyse mit den Mikrozensen 1991-2002. Zeitschrift für Familienforschung, 18, 333357.

Kreyenfeld, M. and Hank, K. (2000). Does the availability of child care influence the employment of mothers? Findings from western Germany. Population Research and Policy Review, 19, 317-337.

Leibowitz, A., Klerman, J. A. and Waite, L. J. (1992). Employment of New Mothers and Child Care Choice. Differences by Children's Age. The Journal of Human Resources, 27, 112.

Lundin, D., Mörk, E. and Öckert, B. (2008). How far can reduced childcare prices push female labour supply? Labour Economics, 15, 647-659.

Morrissey, T. W. (2017). Child care and parent labor force participation. A review of the research literature. Review of Economics of the Household, 15, 1-24.

Müller, K.-U. and Wrohlich, K. (2016). Two Steps Forward One Step Back? Evaluating Contradicting Child Care Policies in Germany. CESifo Economic Studies, 62, 672-698.

Rosenfeld, R. A., Trappe, H. and Gornick, J. C. (2004). Gender and Work in Germany. Before and After Reunification. Annual Review of Sociology, 30, 103-124.

Schober, P. S. (2014). Day Care Trends for Children under Three Years in Germany. In León, M. (Ed.). The transformation of care in European societies. New York: Palgrave Macmillan, pp. 208-232.

Schober, P. S. and Spiess, C. K. (2015). Local Day Care Quality and Maternal Employment. Evidence From East and West Germany. Journal of Marriage and Family, 77, 712-729.

Schober, P. S. and Stahl, J. F. (2014). Childcare Trends in Germany-Increasing SocioEconomic Disparities in East and West. DIW Economic Bulletin, 4, 51-58.

Sigle-Rushton, W. and Waldfogel, J. (2007). Motherhood and women's earnings in AngloAmerican, Continental European, and Nordic Countries. Feminist Economics, 13, 55-91. 
Sjöberg, O. (2004). The Role of Family Policy Institutions in Explaining Gender-Role Attitudes. A Comparative Multilevel Analysis of Thirteen Industrialized Countries. Journal of European Social Policy, 14, 107-123.

Spence, M. (1973). Job Market Signaling. The Quarterly Journal of Economics, 87, 355. Spieß, C. K., Berger, E. M. and Groh-Samberg, O. (2008). Overcoming Disparities and Expanding Access to Early Childhood Services in Germany: Policy Considerations and Funding Options. Florence.

Stets, J. E. and Burke, P. J. (2000). Identity Theory and Social Identity Theory. Social Psychology Quarterly, 63, 224.

Strunz, E. (2015). Kindertagesbetreuung vor Ort - Der Betreuungsatlas 2014. Eine Analyse lokaler Unterschiede. Dortmund.

Wagner, G. G., Frick, J. R. and Schupp, J. (2007). The German Socio-Economic Panel Study (SOEP) - Scope, Evolution and Enhancements. Schmollers Jahrbuch, 127, 139-169.

Ziefle, A. and Gangl, M. (2014). Do Women Respond to Changes in Family Policy? A QuasiExperimental Study of the Duration of Mothers' Employment Interruptions in Germany. European Sociological Review, 30, 562-581.

Zoch, G. and Schober, P. S. (2017). Public Childcare Expansion and Changing Gender Ideologies of Parents in Germany. 5th international pairfam User Conference, Bremen, 31 May-1 June 2017. 


\section{Acknowledgements}

The authors are grateful for helpful comments from participants at the 2016 conference of the ECSR, ESPAnet, RC28, the SOEP User Conference, and research seminars at University of Bamberg.

\section{Funding}

This work was supported by the Bamberg Graduate School of Social Sciences, which is funded by the German Research Foundation (DFG) under the German Excellence Initiative [GSC1024].

\section{Biographies}

Gundula Zoch is a researcher at the Faculty of Social Sciences at the University of Bamberg and a PhD candidate at the Bamberg Graduate School of Social Sciences, which is funded by the German Excellence Initiative. Her main research interests include social and gender inequalities in labour market participation, family processes and how social policies such as childcare impact these processes as well as social stratification over the life course.

Irina Hondralis is a researcher at the Institute of Sociology at Goethe University Frankfurt and a $\mathrm{PhD}$ candidate at the Bamberg Graduate School of Social Sciences, which is funded by the German Excellence Initiative. Her main research interests include labour market gender inequality, labour market dynamics and how social policies affect labour market inequalities over the life course. 


\section{FIGURES AND TABLES}

Figure 1 Average state-subsidised childcare availability for under-three-year-olds over time in our sample (West Germany)

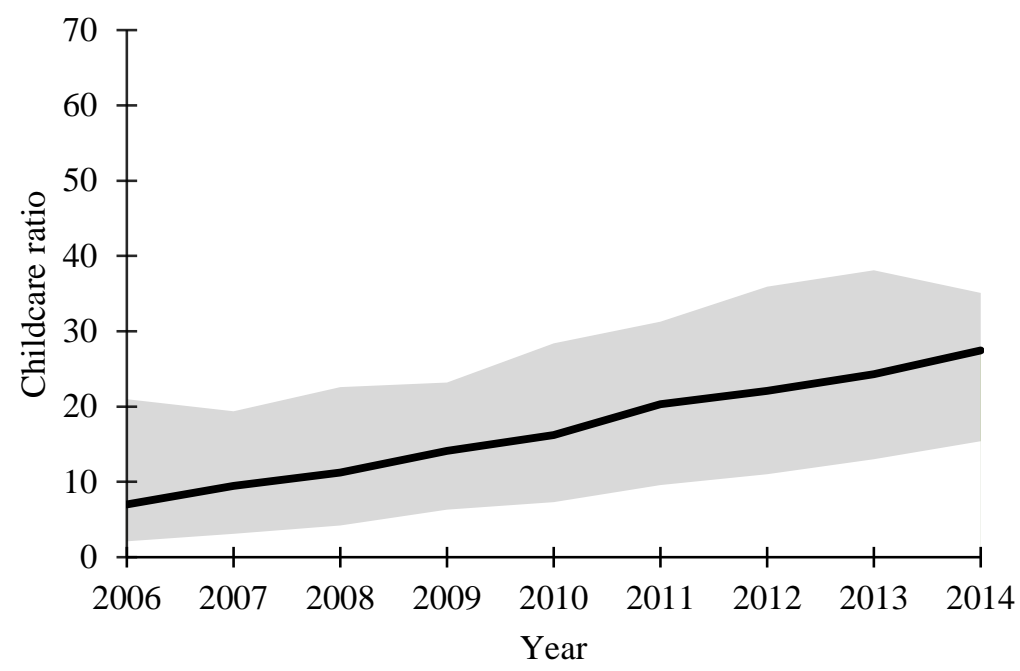

Source: SOEP v31, linked with regional data on the county-level (2006-2014).

Figure 2 Average state-subsidised childcare availability for under-three-year-olds over time in our sample (East Germany)

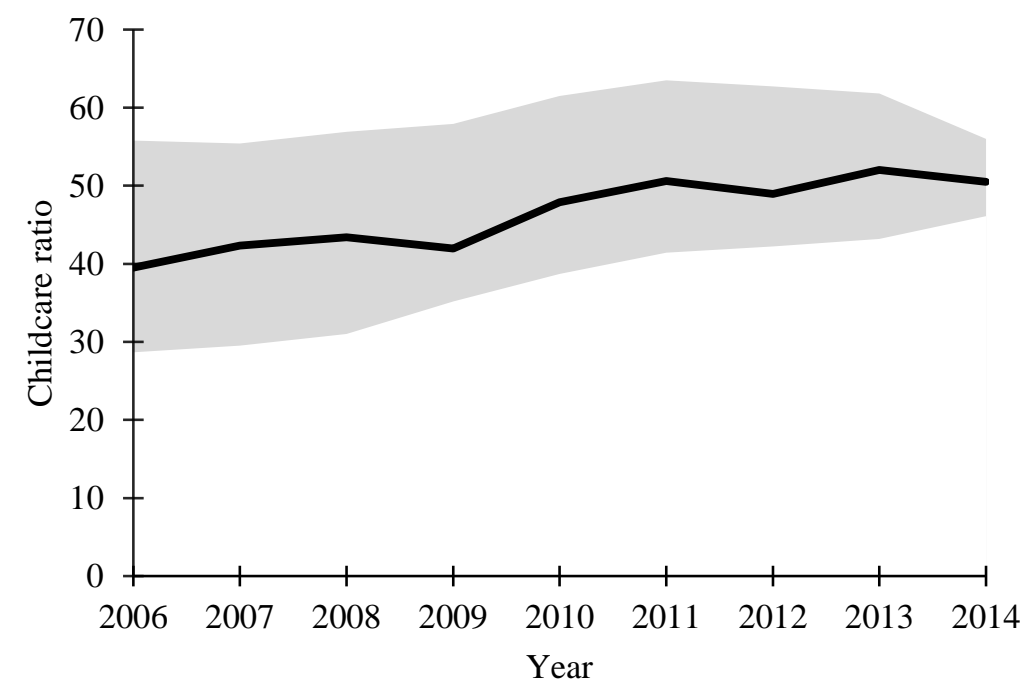

Source: SOEP v31, linked with regional data on the county-level (2006-2014). 
Figure 3 Time-dependency effects for state-subsidised childcare availability (West Germany, all births combined)

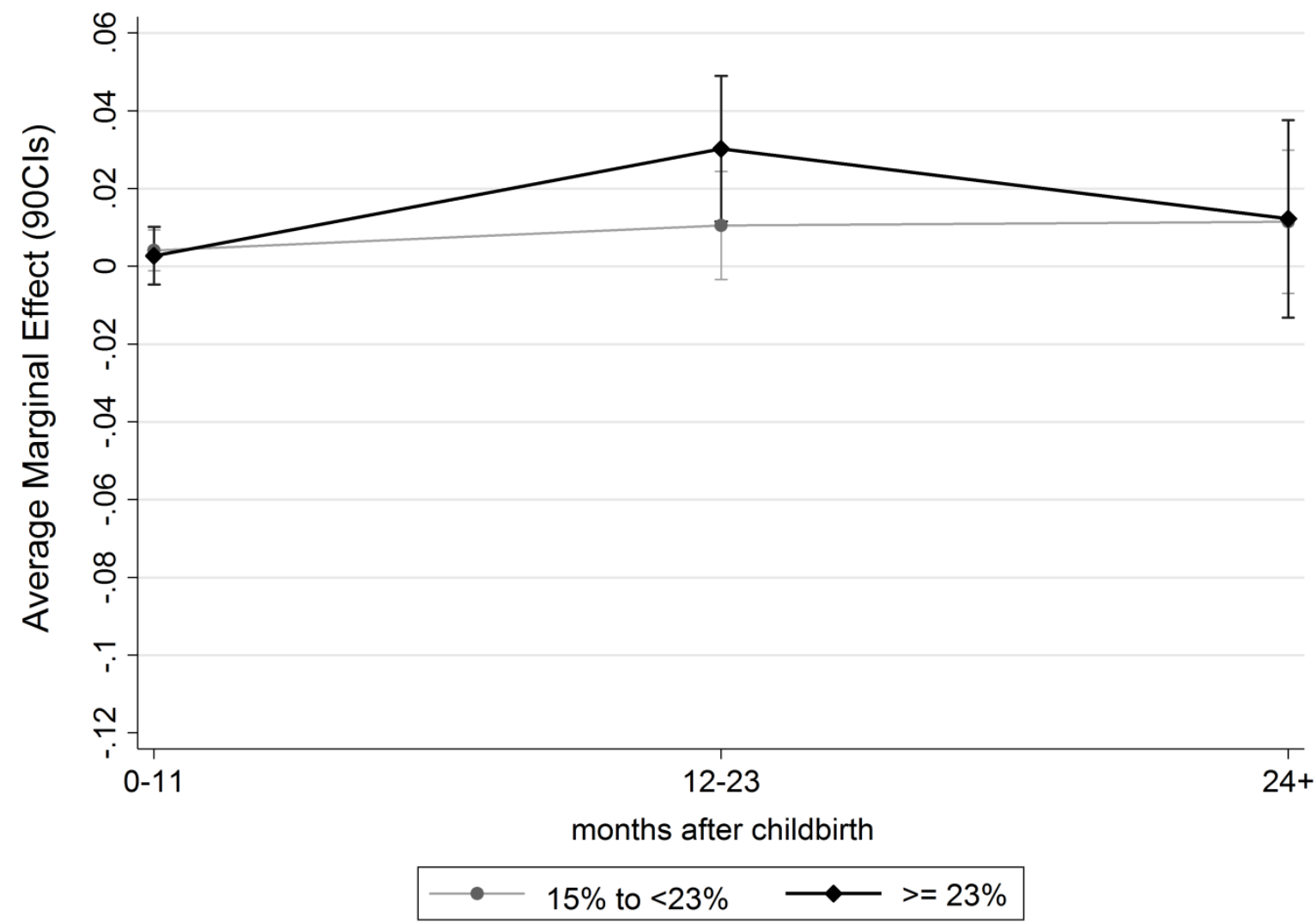

Note: Model includes mother's age and education at birth, mother's employment status and log hourly wage before birth, migration background, marital status, log household income, number of children, year dummies, parental leave period, unemployment rate, female employment rate and marriage rate.

Source: SOEP v31 linked with regional data on the county-level (2006-2014). 
Figure 4 Time-dependency effects for state-subsidised childcare availability (East Germany, all births combined)

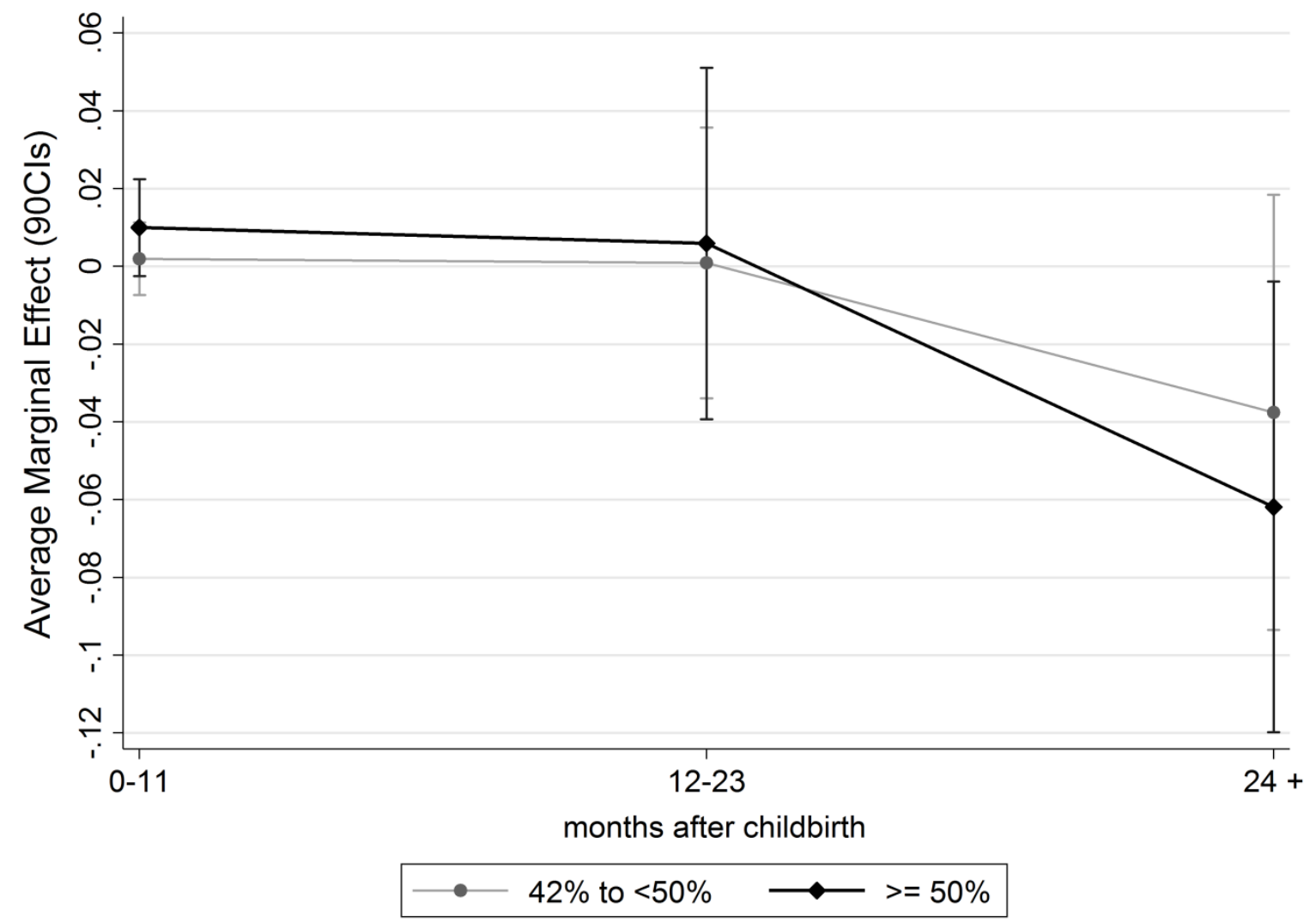

Note: Model includes mother's age and education at birth, mother's employment status and log hourly wage before birth, migration background, marital status, log household income, number of children, year dummies, parental leave period, unemployment rate, female employment rate and marriage rate.

Source: SOEP v31 linked with regional data on the county-level (2006-2014). 
Table 1 Descriptive Statistics (West Germany)

\begin{tabular}{|c|c|c|c|c|c|c|}
\hline \multirow[t]{2}{*}{ West Germany } & \multicolumn{2}{|c|}{ All Births } & \multicolumn{2}{|c|}{ First Births } & \multicolumn{2}{|c|}{ Second Births } \\
\hline & Mean & $S d$ & Mean & $S d$ & Mean & $S d$ \\
\hline Childcare ratio $<15 \%$ & 0.41 & 0.49 & 0.49 & 0.50 & 0.38 & 0.49 \\
\hline Childcare ratio $15 \%$ to $<23 \%$ & 0.39 & 0.49 & 0.33 & 0.47 & 0.42 & 0.49 \\
\hline Childcare ratio $>=23 \%$ & 0.20 & 0.40 & 0.19 & 0.39 & 0.20 & 0.40 \\
\hline \multicolumn{7}{|l|}{ Individual Characteristics } \\
\hline Mother's age at birth of child & 31.62 & 5.17 & 30.11 & 5.56 & 32.17 & 4.90 \\
\hline No vocational degree (Ref.) & 0.16 & 0.36 & 0.12 & 0.33 & 0.11 & 0.31 \\
\hline Vocational degree & 0.59 & 0.49 & 0.60 & 0.49 & 0.62 & 0.48 \\
\hline Tertiary degree & 0.25 & 0.44 & 0.28 & 0.45 & 0.27 & 0.44 \\
\hline Married and cohabiting (Ref.) & 0.82 & 0.38 & 0.74 & 0.44 & 0.87 & 0.34 \\
\hline Cohabiting & 0.11 & 0.31 & 0.16 & 0.37 & 0.08 & 0.27 \\
\hline Single mother & 0.07 & 0.25 & 0.10 & 0.29 & 0.05 & 0.22 \\
\hline German (Ref.) & 0.69 & 0.46 & 0.74 & 0.44 & 0.70 & 0.46 \\
\hline Migration background & 0.31 & 0.46 & 0.26 & 0.44 & 0.30 & 0.46 \\
\hline \multicolumn{7}{|l|}{ Pre-birth employment characteristics } \\
\hline No employment (Ref.) & 0.52 & 0.50 & 0.23 & 0.42 & 0.59 & 0.49 \\
\hline Part-time employment & 0.23 & 0.42 & 0.10 & 0.30 & 0.31 & 0.46 \\
\hline Full-time employment & 0.25 & 0.43 & 0.66 & 0.47 & 0.10 & 0.30 \\
\hline Non-missing employment status (Ref.) & 0.91 & 0.46 & 0.91 & 0.29 & 0.89 & 0.31 \\
\hline Missing employment status & 0.09 & 0.29 & 0.09 & 0.29 & 0.11 & 0.31 \\
\hline Log hourly wage in year before birth (deflated, in $€$ ) & 3.12 & 1.18 & 3.42 & 0.64 & 3.16 & 1.18 \\
\hline \multicolumn{7}{|l|}{ Household Characteristics } \\
\hline Number of children & 2.03 & 0.87 & 1.00 & 0.00 & 2.00 & 0.00 \\
\hline Parental entitlement before 2007 (Ref.) & 0.83 & 0.38 & 0.80 & 0.40 & 0.82 & 0.38 \\
\hline Parental entitlement after 2007 & 0.17 & 0.38 & 0.20 & 0.40 & 0.18 & 0.38 \\
\hline Log household income (deflated, in $€$ ) & 7.17 & 2.09 & 6.79 & 2.47 & 7.21 & 2.03 \\
\hline \multicolumn{7}{|l|}{ Regional Indicators } \\
\hline Unemployment rate & 6.65 & 2.97 & 6.97 & 3.28 & 6.42 & 2.77 \\
\hline Female employment rate & 46.93 & 4.27 & 46.47 & 4.46 & 47.11 & 4.22 \\
\hline Marriage rate & 5.68 & 1.07 & 5.57 & 1.04 & 5.76 & 1.01 \\
\hline
\end{tabular}

Source: SOEP v31 linked with regional data on the county-level (2006-2014). 
Table 2 Descriptive Statistics (East Germany)

\begin{tabular}{|c|c|c|c|c|c|c|}
\hline \multirow[t]{2}{*}{ East Germany } & \multicolumn{2}{|c|}{ All Births } & \multicolumn{2}{|c|}{ First Births } & \multicolumn{2}{|c|}{ Second Births } \\
\hline & Mean & $S d$ & Mean & $S d$ & Mean & $S d$ \\
\hline Childcare ratio $<42 \%$ & 0.31 & 0.46 & 0.30 & 0.46 & 0.30 & 0.46 \\
\hline Childcare ratio $42 \%$ to $<50 \%$ & 0.35 & 0.48 & 0.34 & 0.48 & 0.35 & 0.48 \\
\hline Childcare ratio $>=50 \%$ & 0.34 & 0.47 & 0.36 & 0.48 & 0.35 & 0.48 \\
\hline \multicolumn{7}{|l|}{ Individual Characteristics } \\
\hline Mother's age at birth of child & 30.51 & 4.90 & 28.76 & 4.54 & 30.73 & 4.15 \\
\hline No vocational degree (Ref.) & 0.08 & 0.27 & 0.07 & 0.25 & 0.05 & 0.21 \\
\hline Vocational degree & 0.55 & 0.50 & 0.55 & 0.50 & 0.58 & 0.49 \\
\hline Tertiary degree & 0.38 & 0.48 & 0.39 & 0.49 & 0.38 & 0.49 \\
\hline Married and cohabiting (Ref.) & 0.59 & 0.49 & 0.38 & 0.48 & 0.69 & 0.46 \\
\hline Cohabiting & 0.28 & 0.45 & 0.42 & 0.49 & 0.23 & 0.42 \\
\hline Single mother & 0.13 & 0.33 & 0.20 & 0.40 & 0.09 & 0.28 \\
\hline German (Ref.) & 0.91 & 0.29 & 0.95 & 0.23 & 0.92 & 0.28 \\
\hline Migration background & 0.09 & 0.29 & 0.05 & 0.23 & 0.08 & 0.28 \\
\hline \multicolumn{7}{|l|}{ Pre-birth employment characteristics } \\
\hline No employment (Ref.) & 0.46 & 0.50 & 0.38 & 0.49 & 0.41 & 0.49 \\
\hline Part-time employment & 0.20 & 0.40 & 0.08 & 0.28 & 0.27 & 0.45 \\
\hline Full-time employment & 0.34 & 0.47 & 0.53 & 0.50 & 0.32 & 0.47 \\
\hline Non-missing employment status (Ref.) & 0.87 & 0.33 & 0.82 & 0.38 & 0.95 & 0.23 \\
\hline Missing employment status & 0.13 & 0.33 & 0.18 & 0.38 & 0.05 & 0.23 \\
\hline Log hourly wage in year before birth (deflated, in $€$ ) & 2.37 & 1.35 & 2.68 & 0.92 & 2.35 & 1.46 \\
\hline \multicolumn{7}{|l|}{ Household Characteristics } \\
\hline Number of children & 1.97 & 0.87 & 1.00 & 0.00 & 2.00 & 0.00 \\
\hline Parental entitlement before 2007 (Ref.) & 0.78 & 0.41 & 0.72 & 0.45 & 0.87 & 0.33 \\
\hline Parental entitlement after 2007 & 0.22 & 0.41 & 0.28 & 0.45 & 0.13 & 0.33 \\
\hline Log household income (deflated, in $€$ ) & 6.53 & 2.54 & 5.93 & 2.89 & 6.76 & 2.37 \\
\hline \multicolumn{7}{|l|}{ Regional Indicators } \\
\hline Unemployment rate & 12.91 & 3.17 & 13.59 & 3.54 & 12.67 & 2.77 \\
\hline Female employment rate & 51.36 & 5.10 & 51.25 & 5.55 & 51.18 & 4.81 \\
\hline Marriage rate & 5.14 & 1.60 & 5.21 & 1.82 & 5.04 & 1.50 \\
\hline
\end{tabular}


Table 3: Childcare rate and the duration of employment interruptions following childbirth, piecewise-exponential models

\begin{tabular}{|c|c|c|c|c|c|c|c|c|c|c|c|c|}
\hline \multirow[t]{3}{*}{ West Germany } & \multicolumn{4}{|c|}{ All Births } & \multicolumn{4}{|c|}{ First Births } & \multicolumn{4}{|c|}{ Second Births } \\
\hline & \multicolumn{2}{|c|}{ M1 } & \multicolumn{2}{|c|}{ M2 } & \multicolumn{2}{|c|}{ M3 } & \multicolumn{2}{|c|}{ M4 } & \multicolumn{2}{|c|}{ M5 } & \multicolumn{2}{|c|}{ M6 } \\
\hline & $A M E$ & $S E$ & $A M E$ & $S E$ & $A M E$ & $S E$ & $A M E$ & $S E$ & $A M E$ & $S E$ & $A M E$ & $S E$ \\
\hline Childcare ratio < $15 \%$ (Ref.) & & & & & & & & & & & & \\
\hline Childcare ratio $15 \%$ to $<23 \%$ & $0.009 *$ & $(0.004)$ & $0.006+$ & $(0.003)$ & $0.012+$ & $(0.007)$ & 0.011 & $(0.007)$ & $0.010 *$ & $(0.005)$ & 0.007 & $(0.005)$ \\
\hline Childcare ratio $>=23 \%$ & $0.017 * *$ & $(0.006)$ & $0.010^{*}$ & $(0.005)$ & $0.016+$ & $(0.009)$ & 0.015 & $(0.010)$ & $0.027 * *$ & $(0.008)$ & $0.014^{*}$ & $(0.007)$ \\
\hline Period dummies & \multicolumn{2}{|c|}{$\checkmark$} & \multicolumn{2}{|c|}{$\checkmark$} & \multicolumn{2}{|c|}{$\checkmark$} & \multicolumn{2}{|c|}{$\checkmark$} & \multicolumn{2}{|c|}{$\checkmark$} & \multicolumn{2}{|c|}{$\checkmark$} \\
\hline Individual controls & & & \multicolumn{2}{|c|}{$\checkmark$} & & & \multicolumn{2}{|c|}{$\checkmark$} & & & \multicolumn{2}{|c|}{$\checkmark$} \\
\hline Regional controls & & & \multicolumn{2}{|c|}{$\checkmark$} & & & \multicolumn{2}{|c|}{$\checkmark$} & & & \multicolumn{2}{|c|}{$\checkmark$} \\
\hline Events & \multicolumn{2}{|c|}{553} & \multicolumn{2}{|c|}{553} & \multicolumn{2}{|c|}{207} & \multicolumn{2}{|c|}{207} & \multicolumn{2}{|c|}{254} & \multicolumn{2}{|c|}{254} \\
\hline Observations & \multicolumn{2}{|c|}{17726} & & & & & & 74 & & & & \\
\hline AIC & 490 & 62 & 45 & .58 & 175 & .77 & & 8.51 & 222 & .29 & & .21 \\
\hline $\mathrm{BIC}$ & 498 & .44 & 472 & .93 & 182 & .67 & & 3.25 & 229 & .85 & & .12 \\
\hline Log Likelihood & -24 & .31 & -22 & 5.29 & & .89 & & 4.26 & -11 & .64 & & 60 \\
\hline East Germany & & All & ths & & & First & rths & & & Secon & irths & \\
\hline & & & & & & & & 14 & & & & \\
\hline & $A M E$ & $S E$ & $A M E$ & $S E$ & $A M E$ & $S E$ & $A M E$ & $S E$ & $A M E$ & $S E$ & $A M E$ & SE \\
\hline Childcare rate $<42 \%$ (Ref.) & & & & & & & & & & & & \\
\hline Childcare rate $42 \%$ to $<50 \%$ & 0.003 & $(0.007)$ & -0.000 & $(0.007)$ & 0.008 & $(0.014)$ & 0.022 & $(0.014)$ & 0.005 & $(0.013)$ & 0.009 & $(0.012)$ \\
\hline Childcare rate $>=50 \%$ & 0.008 & $(0.009)$ & 0.003 & $(0.010)$ & 0.000 & $(0.013)$ & 0.014 & $(0.018)$ & 0.013 & $(0.017)$ & 0.020 & $(0.022)$ \\
\hline Period dummies & & & & & & & & l & & & & \\
\hline Individual controls & & & & & & & & / & & & & \\
\hline Regional controls & & & & & & & & / & & & & \\
\hline Events & & & & & & & & 9 & & & & \\
\hline Observations & & & & & & & & 28 & & & & \\
\hline AIC & 138 & 88 & 13 & 18 & & & & 6.51 & & & & 83 \\
\hline $\mathrm{BIC}$ & 145 & 25 & 151 & .94 & & & & 3.11 & & & & 94 \\
\hline Log Likelihood & -68 & 94 & -64 & .09 & & .65 & & 3.25 & -30 & 88 & & .91 \\
\hline
\end{tabular}


Table 4 Childcare rate and the duration of employment interruptions following childbirth, competing risks model

\begin{tabular}{|c|c|c|c|c|c|c|c|c|}
\hline \multirow[t]{3}{*}{ West Germany } & \multicolumn{4}{|c|}{ Substantial Return } & \multicolumn{4}{|c|}{ Marginal Return } \\
\hline & \multicolumn{2}{|c|}{ M1 } & \multicolumn{2}{|c|}{ M2 } & \multicolumn{2}{|c|}{ M3 } & \multicolumn{2}{|c|}{ M4 } \\
\hline & $A M E$ & $S E$ & $A M E$ & $S E$ & $A M E$ & $S E$ & $A M E$ & $S E$ \\
\hline \multicolumn{9}{|l|}{ Childcare ratio $<15 \%$ (Ref.) } \\
\hline Childcare ratio $15 \%$ to $<23 \%$ & $0.008 * *$ & $(0.003)$ & $0.006^{*}$ & $(0.003)$ & 0.000 & $(0.002)$ & 0.000 & $(0.002)$ \\
\hline Childcare ratio $>=23 \%$ & $0.016^{* *}$ & $(0.004)$ & $0.008^{*}$ & $(0.004)$ & 0.002 & $(0.003)$ & 0.002 & $(0.003)$ \\
\hline Period dummies & \multicolumn{2}{|c|}{$\checkmark$} & \multicolumn{2}{|c|}{$\checkmark$} & \multicolumn{2}{|c|}{$\checkmark$} & \multicolumn{2}{|c|}{$\checkmark$} \\
\hline Individual controls & & & \multicolumn{2}{|c|}{$\checkmark$} & & & \multicolumn{2}{|c|}{$\checkmark$} \\
\hline Regional controls & & & \multicolumn{2}{|c|}{$\checkmark$} & & & \multicolumn{2}{|c|}{$\checkmark$} \\
\hline Events & \multicolumn{2}{|c|}{368} & \multicolumn{2}{|c|}{368} & \multicolumn{2}{|c|}{185} & \multicolumn{2}{|c|}{185} \\
\hline Observations & \multicolumn{2}{|c|}{17070} & \multicolumn{2}{|c|}{17070} & \multicolumn{2}{|c|}{16881} & \multicolumn{2}{|c|}{16881} \\
\hline AIC & \multicolumn{2}{|c|}{3562.24} & \multicolumn{2}{|c|}{3230.23} & \multicolumn{2}{|c|}{1997.47} & \multicolumn{2}{|c|}{1918.62} \\
\hline BIC & \multicolumn{2}{|c|}{3639.69} & \multicolumn{2}{|c|}{3431.61} & \multicolumn{2}{|c|}{2074.81} & 21 & .70 \\
\hline Log Likelihood & -17 & .12 & -15 & .12 & & 3.74 & & .31 \\
\hline East Germany & & Substan & Return & & & Margil & Return & \\
\hline & & & & & & 3 & & \\
\hline & $A M E$ & $S E$ & $A M E$ & $S E$ & $A M E$ & $S E$ & $A M E$ & $S E$ \\
\hline Childcare rate $<42 \%$ (Ref.) & & & & & & & & \\
\hline Childcare rate $42 \%$ to $<50 \%$ & 0.006 & $(0.007)$ & 0.003 & $(0.006)$ & -0.001 & $(0.004)$ & -0.004 & $(0.005)$ \\
\hline Childcare rate $>=50 \%$ & 0.011 & $(0.008)$ & 0.007 & $(0.010)$ & -0.002 & $(0.004)$ & -0.006 & $(0.005)$ \\
\hline Period dummies & & & & & & l & & \\
\hline Individual controls & & & & & & & & \\
\hline Regional controls & & & & & & & & \\
\hline Events & & & & & & 7 & & \\
\hline Observations & & & & & & 98 & & \\
\hline AIC & 121 & 88 & & .94 & & 60 & & 42 \\
\hline $\mathrm{BIC}$ & 128 & .85 & & 67 & & .29 & & 39 \\
\hline Log Likelihood & -59 & .44 & & & & 9.30 & & .21 \\
\hline
\end{tabular}

Note: Full model include mother's age and education at birth, mother's employment status and log hourly wage before birth, migration background, marital status, log household income, number of children, year dummies, parental leave period, unemployment rate, female employment rate and marriage rate.

$+p<0.10, * p<0.05, * * p<0.01$, robust standard errors in parentheses.

Source: SOEP v31 linked with regional data on the county-level (2006-2014). 
APPENDIX

Table A1 Distribution of childcare availability over the observation period

\begin{tabular}{|c|c|c|c|c|c|c|c|c|c|c|}
\hline \multicolumn{11}{|c|}{ Year of observation } \\
\hline West Germany & 2006 & 2007 & 2008 & 2009 & 2010 & 2011 & 2012 & 2013 & 2014 & Total \\
\hline Childcare ratio $<15 \%$ & 97.27 & 89.79 & 80.07 & 65.09 & 42.28 & 20.01 & 14.02 & 4.87 & 0.00 & 100.00 \\
\hline Childcare ratio $15 \%$ to $<23 \%$ & 2.73 & 10.21 & 19.93 & 31.45 & 45.94 & 56.93 & 50.03 & 47.10 & 16.38 & 100.00 \\
\hline Childcare ratio $>=23 \%$ & 0.00 & 0.00 & 0.00 & 3.46 & 11.78 & 23.07 & 35.94 & 48.02 & 83.62 & 100.00 \\
\hline Total & 100.00 & 100.00 & 100.00 & 100.00 & 100.00 & 100.00 & 100.00 & 100.00 & 100.00 & 100.00 \\
\hline East Germany & 2006 & 2007 & 2008 & 2009 & 2010 & 2011 & 2012 & 2013 & 2014 & Total \\
\hline Childcare ratio $<42 \%$ & 67.42 & 44.05 & 41.77 & 53.00 & 40.39 & 8.60 & 2.33 & 0.00 & 0.00 & 100.00 \\
\hline Childcare ratio $42 \%$ to $<50 \%$ & 21.12 & 40.08 & 40.53 & 21.66 & 27.72 & 42.83 & 40.31 & 46.93 & 41.67 & 100.00 \\
\hline Childcare ratio $>=50 \%$ & 11.46 & 15.87 & 17.70 & 23.35 & 31.89 & 48.57 & 57.36 & 53.07 & 58.33 & 100.00 \\
\hline Total & 100.00 & 100.00 & 100.00 & 100.00 & 100.00 & 100.00 & 100.00 & 100.00 & 100.00 & 100.00 \\
\hline
\end{tabular}

Source: SOEP v31 linked with regional data on the county-level (2006-2014). 
Table A2 Childcare rate and the duration of employment interruptions, full piecewise-exponential models (West Germany)

\begin{tabular}{|c|c|c|c|c|c|c|c|c|c|}
\hline \multirow[t]{3}{*}{ West Germany } & \multicolumn{3}{|c|}{ All Births } & \multicolumn{3}{|c|}{ First Births } & \multicolumn{3}{|c|}{ Second Births } \\
\hline & \multicolumn{3}{|c|}{ M1 } & \multicolumn{3}{|c|}{ M2 } & \multicolumn{3}{|c|}{ M3 } \\
\hline & $A M E$ & $S E$ & $C I$ & $A M E$ & $S E$ & $C I$ & $A M E$ & $S E$ & $C I$ \\
\hline \multicolumn{10}{|l|}{ 0-11 months (Ref.) } \\
\hline $12-23$ months & $0.032 * *$ & $(0.005)$ & {$[0.023,0.041]$} & $0.034 * *$ & $(0.009)$ & {$[0.015,0.053]$} & $0.037 * *$ & $(0.007)$ & {$[0.022,0.051]$} \\
\hline \multicolumn{10}{|l|}{ Childcare ratio $<15 \%$ (Ref.) } \\
\hline Childcare ratio $15 \%$ to $<23 \%$ & $0.006+$ & $(0.003)$ & {$[-0.000,0.013]$} & 0.011 & $(0.007)$ & {$[-0.003,0.024]$} & 0.007 & $(0.005)$ & {$[-0.002,0.017]$} \\
\hline Childcare ratio $>=23 \%$ & $0.010^{*}$ & $(0.005)$ & {$[0.000,0.020]$} & 0.015 & $(0.010)$ & {$[-0.005,0.035]$} & $0.014 *$ & $(0.007)$ & {$[0.000,0.029]$} \\
\hline Number of Children & -0.001 & $(0.002)$ & {$[-0.005,0.003]$} & & & & & & \\
\hline \multicolumn{10}{|l|}{ No vocational degree (Ref.) } \\
\hline Vocational degree & $0.008^{*}$ & $(0.004)$ & {$[0.000,0.016]$} & -0.001 & $(0.011)$ & {$[-0.022,0.021]$} & $0.015 * *$ & $(0.005)$ & {$[0.005,0.025]$} \\
\hline Tertiary degree & $0.019 * *$ & $(0.005)$ & {$[0.009,0.030]$} & 0.008 & $(0.014)$ & {$[-0.018,0.035]$} & $0.029 * *$ & $(0.007)$ & {$[0.016,0.042]$} \\
\hline \multicolumn{10}{|l|}{ No employment (Ref.) } \\
\hline Part-time Employment & $0.026 * *$ & $(0.004)$ & {$[0.018,0.034]$} & $0.022 *$ & $(0.011)$ & {$[0.001,0.043]$} & $0.027 * *$ & $(0.007)$ & {$[0.013,0.041]$} \\
\hline Full-time Employment & $0.027 * *$ & $(0.005)$ & {$[0.017,0.036]$} & $0.032 * *$ & $(0.009)$ & {$[0.015,0.049]$} & $0.029 * *$ & $(0.010)$ & {$[0.008,0.049]$} \\
\hline Missing employment status (Ref.: non-missing) & $0.013^{*}$ & $(0.006)$ & {$[0.000,0.026]$} & $0.028+$ & $(0.016)$ & {$[-0.003,0.060]$} & 0.009 & $(0.010)$ & {$[-0.011,0.029]$} \\
\hline Log hourly wage & 0.002 & $(0.002)$ & {$[-0.001,0.005]$} & 0.002 & $(0.006)$ & {$[-0.011,0.014]$} & -0.000 & $(0.002)$ & {$[-0.004,0.004]$} \\
\hline Log household income & $-0.007 * *$ & $(0.001)$ & {$[-0.008,-0.006]$} & $-0.006 * *$ & $(0.001)$ & {$[-0.008,-0.004]$} & $-0.008 * *$ & $(0.001)$ & {$[-0.010,-0.006]$} \\
\hline \multicolumn{10}{|l|}{ Married and cohabiting (Ref.) } \\
\hline Single Mother & -0.001 & $(0.006)$ & {$[-0.012,0.010]$} & 0.003 & $(0.009)$ & {$[-0.014,0.020]$} & -0.013 & $(0.009)$ & {$[-0.030,0.005]$} \\
\hline Migration Background (Ref.: German) & $-0.013 * *$ & $(0.003)$ & {$[-0.019,-0.007]$} & $-0.017 * *$ & $(0.006)$ & {$[-0.029,-0.004]$} & -0.008 & $(0.005)$ & {$[-0.017,0.002]$} \\
\hline Parental leave reform 2007 (Ref.: 2006) & -0.001 & $(0.006)$ & {$[-0.013,0.011]$} & -0.014 & $(0.011)$ & {$[-0.036,0.008]$} & 0.010 & $(0.009)$ & {$[-0.007,0.028]$} \\
\hline Unemployment rate & -0.000 & $(0.001)$ & {$[-0.001,0.001]$} & 0.000 & $(0.001)$ & {$[-0.002,0.003]$} & 0.000 & $(0.001)$ & {$[-0.002,0.002]$} \\
\hline Female employment rate & -0.000 & $(0.001)$ & {$[-0.001,0.001]$} & 0.000 & $(0.001)$ & {$[-0.002,0.002]$} & -0.000 & $(0.001)$ & {$[-0.002,0.001]$} \\
\hline Marriage rate & 0.002 & $(0.001)$ & {$[-0.000,0.005]$} & $0.005+$ & $(0.003)$ & {$[-0.001,0.010]$} & 0.000 & $(0.002)$ & {$[-0.003,0.004]$} \\
\hline Events & \multicolumn{3}{|c|}{553} & \multicolumn{3}{|c|}{207} & \multicolumn{3}{|c|}{254} \\
\hline Observations & \multicolumn{3}{|c|}{17726} & \multicolumn{3}{|c|}{5374} & \multicolumn{3}{|c|}{7759} \\
\hline AIC & \multicolumn{3}{|c|}{4544.58} & \multicolumn{3}{|c|}{1718.51} & \multicolumn{3}{|c|}{2047.21} \\
\hline BIC & \multirow{2}{*}{\multicolumn{3}{|c|}{4746.93}} & \multicolumn{3}{|c|}{1883.25} & \multicolumn{3}{|c|}{2221.12} \\
\hline Log Likelihood & \multicolumn{2}{|c|}{-2246.29} & & \multicolumn{3}{|c|}{-834.26} & \multicolumn{3}{|c|}{-998.60} \\
\hline
\end{tabular}

Note: $+p<0.10, * p<0.05, * * p<0.01$, robust standard errors in parentheses.

Source: SOEP v31 linked with regional data on the county-level (2006-2014). 
Table A3 Childcare rate and the duration of employment interruptions, full piecewise-exponential models (East Germany)

\begin{tabular}{|c|c|c|c|c|c|c|c|c|c|}
\hline \multirow[t]{3}{*}{ East Germany } & \multicolumn{3}{|c|}{ All Births } & \multicolumn{3}{|c|}{ First Births } & \multicolumn{3}{|c|}{ Second Births } \\
\hline & \multicolumn{3}{|c|}{ M1 } & \multicolumn{3}{|c|}{ M2 } & \multicolumn{3}{|c|}{ M3 } \\
\hline & $A M E$ & $S E$ & $C I$ & $A M E$ & $S E$ & $C I$ & $A M E$ & $S E$ & $C I$ \\
\hline \multicolumn{10}{|l|}{ 0-11 months (Ref.) } \\
\hline $12-23$ months & $0.046^{* *}$ & $(0.013)$ & {$[0.020,0.071]$} & $0.058 *$ & $(0.023)$ & {$[0.012,0.103]$} & $0.061 * *$ & $(0.022)$ & {$[0.017,0.105]$} \\
\hline \multicolumn{10}{|l|}{ Childcare ratio $<42 \%$ (Ref.) } \\
\hline Childcare ratio $42 \%$ to $<50 \%$ & -0.000 & $(0.007)$ & {$[-0.013,0.013]$} & 0.022 & $(0.014)$ & {$[-0.007,0.050]$} & 0.009 & $(0.012)$ & {$[-0.015,0.032]$} \\
\hline Childcare ratio $>=50 \%$ & 0.003 & $(0.010)$ & {$[-0.017,0.023]$} & 0.014 & $(0.018)$ & {$[-0.022,0.050]$} & 0.020 & $(0.022)$ & {$[-0.022,0.062]$} \\
\hline Number of Children & -0.005 & $(0.004)$ & {$[-0.014,0.003]$} & & & & & & \\
\hline \multicolumn{10}{|l|}{ No vocational degree (Ref.) } \\
\hline Vocational degree & 0.007 & $(0.014)$ & {$[-0.020,0.034]$} & 0.005 & $(0.017)$ & {$[-0.029,0.038]$} & -0.054 & $(0.038)$ & {$[-0.129,0.021]$} \\
\hline Tertiary degree & 0.016 & $(0.014)$ & {$[-0.011,0.043]$} & $0.052 *$ & $(0.024)$ & {$[0.004,0.100]$} & -0.056 & $(0.035)$ & {$[-0.125,0.012]$} \\
\hline \multicolumn{10}{|l|}{ No employment (Ref.) } \\
\hline Part-time Employment & $0.027 * *$ & $(0.010)$ & {$[0.007,0.047]$} & $0.031+$ & $(0.019)$ & {$[-0.005,0.068]$} & $0.045^{*}$ & $(0.021)$ & {$[0.004,0.085]$} \\
\hline Full-time Employment & $0.021 *$ & $(0.011)$ & {$[0.000,0.042]$} & 0.006 & $(0.016)$ & {$[-0.024,0.037]$} & $0.036+$ & $(0.019)$ & {$[-0.000,0.072]$} \\
\hline Missing employment status (Ref.: non-missing) & $-0.022+$ & $(0.012)$ & {$[-0.046,0.002]$} & -0.041 & $(0.026)$ & {$[-0.093,0.011]$} & 0.005 & $(0.027)$ & {$[-0.048,0.058]$} \\
\hline Log hourly wage & $0.008 * *$ & $(0.003)$ & {$[0.003,0.014]$} & 0.007 & $(0.007)$ & {$[-0.006,0.020]$} & $0.011 *$ & $(0.005)$ & {$[0.002,0.020]$} \\
\hline Log household income & $-0.003+$ & $(0.002)$ & {$[-0.006,0.000]$} & -0.004 & $(0.003)$ & {$[-0.009,0.001]$} & -0.002 & $(0.003)$ & {$[-0.008,0.005]$} \\
\hline \multicolumn{10}{|l|}{ Married and cohabiting (Ref.) } \\
\hline Single Mother & $-0.016^{*}$ & $(0.007)$ & {$[-0.029,-0.003]$} & $-0.022+$ & $(0.013)$ & {$[-0.047,0.004]$} & -0.023 & $(0.016)$ & {$[-0.054,0.009]$} \\
\hline Migration Background (Ref.: German) & 0.008 & $(0.008)$ & {$[-0.008,0.024]$} & $0.033 *$ & $(0.014)$ & {$[0.004,0.061]$} & 0.024 & $(0.021)$ & {$[-0.018,0.066]$} \\
\hline Parental leave reform 2007 (Ref.: 2006) & $0.017+$ & $(0.010)$ & {$[-0.003,0.037]$} & 0.012 & $(0.020)$ & {$[-0.027,0.052]$} & $0.049 * *$ & $(0.018)$ & {$[0.014,0.084]$} \\
\hline Unemployment rate & -0.000 & $(0.002)$ & {$[-0.003,0.003]$} & -0.001 & $(0.003)$ & {$[-0.008,0.005]$} & -0.003 & $(0.003)$ & {$[-0.008,0.002]$} \\
\hline Female employment rate & -0.000 & $(0.001)$ & {$[-0.002,0.002]$} & -0.001 & $(0.002)$ & {$[-0.005,0.003]$} & 0.000 & $(0.002)$ & {$[-0.004,0.004]$} \\
\hline Marriage rate & 0.003 & $(0.002)$ & {$[-0.001,0.006]$} & 0.005 & $(0.003)$ & {$[-0.001,0.012]$} & 0.003 & $(0.003)$ & {$[-0.003,0.009]$} \\
\hline Events & \multicolumn{3}{|c|}{166} & \multicolumn{3}{|c|}{59} & \multicolumn{3}{|c|}{77} \\
\hline Observations & \multicolumn{3}{|c|}{4176} & \multicolumn{3}{|c|}{1428} & \multicolumn{3}{|c|}{1710} \\
\hline AIC & \multicolumn{3}{|c|}{1348.18} & \multicolumn{3}{|c|}{496.51} & \multicolumn{3}{|c|}{617.83} \\
\hline $\mathrm{BIC}$ & \multicolumn{3}{|c|}{1512.94} & \multicolumn{3}{|c|}{628.11} & \multicolumn{3}{|c|}{753.94} \\
\hline Log Likelihood & \multicolumn{3}{|c|}{-648.09} & \multicolumn{3}{|c|}{-223.25} & \multicolumn{3}{|c|}{-283.91} \\
\hline
\end{tabular}

Note: $+p<0.10 * p<0.05, * * p<0.01$, robust standard errors in parentheses.

Source: SOEP v31 linked with regional data on the county-level (2006-2014). 
Table A4 Competing risks model, full models (West Germany)

\begin{tabular}{|c|c|c|c|c|c|c|}
\hline \multirow[t]{3}{*}{ West Germany } & \multicolumn{3}{|c|}{ Substantial Return } & \multicolumn{3}{|c|}{ Marginal Return } \\
\hline & \multicolumn{3}{|c|}{$\mathrm{M} 1$} & \multicolumn{3}{|c|}{ M2 } \\
\hline & $A M E$ & $S E$ & $C I$ & $A M E$ & $S E$ & $C I$ \\
\hline \multicolumn{7}{|l|}{ 0-11 months (Ref.) } \\
\hline $12-23$ months & $0.023 * *$ & $(0.004)$ & {$[0.014,0.031]$} & $0.011 * *$ & $(0.003)$ & {$[0.006,0.017]$} \\
\hline 24 months or longer & $0.033 * *$ & $(0.007)$ & {$[0.020,0.046]$} & $0.012 * *$ & $(0.004)$ & {$[0.005,0.020]$} \\
\hline \multicolumn{7}{|l|}{ Childcare ratio $<15 \%$ (Ref.) } \\
\hline Childcare ratio $15 \%$ to $<23 \%$ & $0.006 *$ & $(0.003)$ & {$[0.000,0.011]$} & 0.000 & $(0.002)$ & {$[-0.004,0.005]$} \\
\hline Childcare ratio $>=23 \%$ & $0.008^{*}$ & $(0.004)$ & {$[0.000,0.016]$} & 0.002 & $(0.003)$ & {$[-0.004,0.009]$} \\
\hline Number of Children & -0.002 & $(0.002)$ & {$[-0.006,0.001]$} & 0.001 & $(0.001)$ & {$[-0.001,0.003]$} \\
\hline Mother's age at birth of child & 0.000 & $(0.000)$ & {$[-0.000,0.001]$} & $-0.001 * *$ & $(0.000)$ & {$[-0.001,-0.000]$} \\
\hline \multicolumn{7}{|l|}{ No vocational degree (Ref.) } \\
\hline Vocational degree & $0.006+$ & $(0.003)$ & {$[-0.000,0.013]$} & 0.003 & $(0.002)$ & {$[-0.002,0.008]$} \\
\hline Tertiary degree & $0.020 * *$ & $(0.005)$ & {$[0.010,0.029]$} & 0.000 & $(0.003)$ & {$[-0.005,0.006]$} \\
\hline \multicolumn{7}{|l|}{ No employment (Ref.) } \\
\hline Part-time Employment & $0.022 * *$ & $(0.004)$ & {$[0.015,0.030]$} & $0.007 *$ & $(0.003)$ & {$[0.001,0.014]$} \\
\hline Full-time Employment & $0.025 * *$ & $(0.004)$ & {$[0.017,0.033]$} & 0.003 & $(0.003)$ & {$[-0.003,0.009]$} \\
\hline Missing employment status (Ref.: non-missing) & $0.015^{*}$ & $(0.006)$ & {$[0.003,0.027]$} & 0.002 & $(0.004)$ & {$[-0.006,0.010]$} \\
\hline Log hourly wage & 0.002 & $(0.002)$ & {$[-0.001,0.005]$} & 0.000 & $(0.001)$ & {$[-0.001,0.002]$} \\
\hline Log household income & $-0.005 * *$ & $(0.001)$ & {$[-0.006,-0.004]$} & $-0.003 * *$ & $(0.000)$ & {$[-0.003,-0.002]$} \\
\hline \multicolumn{7}{|l|}{ Married and cohabiting (Ref.) } \\
\hline Cohabiting & 0.001 & $(0.003)$ & {$[-0.005,0.007]$} & $-0.006 * *$ & $(0.002)$ & {$[-0.010,-0.003]$} \\
\hline Single Mother & 0.005 & $(0.006)$ & {$[-0.007,0.017]$} & -0.005 & $(0.003)$ & {$[-0.010,0.001]$} \\
\hline Migration Background (Ref.: German) & $-0.008 * *$ & $(0.003)$ & {$[-0.014,-0.003]$} & $-0.005^{*}$ & $(0.002)$ & {$[-0.009,-0.001]$} \\
\hline Parental leave reform 2007 (Ref.: 2006) & -0.003 & $(0.005)$ & {$[-0.014,0.008]$} & 0.000 & $(0.004)$ & {$[-0.008,0.008]$} \\
\hline Unemployment rate & 0.000 & $(0.001)$ & {$[-0.001,0.001]$} & -0.000 & $(0.000)$ & {$[-0.001,0.000]$} \\
\hline Female employment rate & -0.000 & $(0.000)$ & {$[-0.001,0.001]$} & 0.000 & $(0.000)$ & {$[-0.001,0.001]$} \\
\hline Marriage rate & 0.002 & $(0.001)$ & {$[-0.001,0.004]$} & 0.000 & $(0.001)$ & {$[-0.001,0.002]$} \\
\hline Events & \multicolumn{3}{|c|}{368} & \multicolumn{3}{|c|}{185} \\
\hline Observations & \multicolumn{3}{|c|}{17070} & \multicolumn{3}{|c|}{16881} \\
\hline AIC & \multicolumn{3}{|c|}{3230.23} & \multicolumn{3}{|c|}{1918.62} \\
\hline $\mathrm{BIC}$ & \multicolumn{3}{|c|}{3431.61} & \multicolumn{3}{|c|}{2119.70} \\
\hline Log Likelihood & \multicolumn{3}{|c|}{-1589.12} & \multicolumn{3}{|c|}{-933.31} \\
\hline
\end{tabular}


Table A5 Competing risks model, full models (East Germany)

\begin{tabular}{|c|c|c|c|c|c|c|}
\hline \multirow[t]{3}{*}{ East Germany } & \multicolumn{3}{|c|}{ Substantial Return } & \multicolumn{3}{|c|}{ Marginal Return } \\
\hline & \multicolumn{3}{|c|}{$\mathrm{M} 1$} & \multicolumn{3}{|c|}{ M2 } \\
\hline & $A M E$ & $S E$ & $C I$ & $A M E$ & $S E$ & $C I$ \\
\hline \multicolumn{7}{|l|}{ 0-11 months (Ref.) } \\
\hline $12-23$ months & $0.042 * *$ & $(0.013)$ & {$[0.016,0.067]$} & $0.006^{*}$ & $(0.003)$ & {$[0.000,0.011]$} \\
\hline 24 months or longer & $0.052 * *$ & $(0.019)$ & {$[0.015,0.090]$} & $0.021 *$ & $(0.008)$ & {$[0.005,0.038]$} \\
\hline \multicolumn{7}{|l|}{ Childcare ratio < $42 \%$ (Ref.) } \\
\hline Childcare ratio $42 \%$ to $<50 \%$ & 0.003 & $(0.006)$ & {$[-0.009,0.015]$} & -0.004 & $(0.005)$ & {$[-0.013,0.006]$} \\
\hline Childcare ratio $>=50 \%$ & 0.007 & $(0.010)$ & {$[-0.012,0.027]$} & -0.006 & $(0.005)$ & {$[-0.017,0.004]$} \\
\hline Number of Children & -0.006 & $(0.004)$ & {$[-0.015,0.002]$} & 0.000 & $(0.001)$ & {$[-0.002,0.002]$} \\
\hline Mother's age at birth of child & 0.001 & $(0.001)$ & {$[-0.001,0.002]$} & 0.000 & $(0.000)$ & {$[-0.000,0.001]$} \\
\hline \multicolumn{7}{|l|}{ No vocational degree (Ref.) } \\
\hline Vocational degree & $0.023^{*}$ & $(0.009)$ & {$[0.005,0.042]$} & -0.018 & $(0.017)$ & {$[-0.051,0.014]$} \\
\hline Tertiary degree & $0.027 * *$ & $(0.008)$ & {$[0.012,0.042]$} & -0.015 & $(0.018)$ & {$[-0.049,0.020]$} \\
\hline \multicolumn{7}{|l|}{ No employment (Ref.) } \\
\hline Part-time Employment & $0.037 * *$ & $(0.012)$ & {$[0.014,0.061]$} & -0.006 & $(0.005)$ & {$[-0.015,0.004]$} \\
\hline Full-time Employment & $0.023 *$ & $(0.011)$ & {$[0.001,0.045]$} & -0.002 & $(0.006)$ & {$[-0.013,0.009]$} \\
\hline Missing employment status (Ref.: non-missing) & -0.016 & $(0.014)$ & {$[-0.043,0.012]$} & -0.003 & $(0.006)$ & {$[-0.015,0.009]$} \\
\hline Log hourly wage & $0.008 *$ & $(0.004)$ & {$[0.001,0.015]$} & 0.001 & $(0.003)$ & {$[-0.004,0.006]$} \\
\hline Log household income & $-0.003+$ & $(0.002)$ & {$[-0.006,0.000]$} & -0.000 & $(0.001)$ & {$[-0.002,0.001]$} \\
\hline \multicolumn{7}{|l|}{ Married and cohabiting (Ref.) } \\
\hline Cohabiting & $0.018^{*}$ & $(0.007)$ & {$[0.004,0.033]$} & 0.002 & $(0.004)$ & {$[-0.006,0.011]$} \\
\hline Single Mother & $-0.013+$ & $(0.008)$ & {$[-0.029,0.002]$} & 0.002 & $(0.004)$ & {$[-0.006,0.010]$} \\
\hline Migration Background (Ref.: German) & 0.006 & $(0.011)$ & {$[-0.016,0.028]$} & 0.003 & $(0.008)$ & {$[-0.013,0.019]$} \\
\hline Parental leave reform 2007 (Ref.: 2006) & 0.013 & $(0.012)$ & {$[-0.011,0.038]$} & 0.000 & $(0.007)$ & {$[-0.013,0.014]$} \\
\hline Unemployment rate & -0.002 & $(0.001)$ & {$[-0.004,0.001]$} & $0.002 *$ & $(0.001)$ & {$[0.000,0.003]$} \\
\hline Female employment rate & -0.001 & $(0.001)$ & {$[-0.002,0.001]$} & 0.000 & $(0.000)$ & {$[-0.001,0.001]$} \\
\hline Marriage rate & $0.004+$ & $(0.002)$ & {$[-0.000,0.007]$} & 0.000 & $(0.001)$ & {$[-0.002,0.002]$} \\
\hline Events & \multicolumn{3}{|c|}{139} & \multicolumn{3}{|c|}{27} \\
\hline Observations & \multicolumn{3}{|c|}{4013} & \multicolumn{3}{|c|}{3898} \\
\hline AIC & \multicolumn{3}{|c|}{1169.94} & \multicolumn{3}{|c|}{316.42} \\
\hline $\mathrm{BIC}$ & \multicolumn{3}{|c|}{1333.67} & \multicolumn{3}{|c|}{479.39} \\
\hline Log Likelihood & \multicolumn{3}{|c|}{-558.97} & \multicolumn{3}{|c|}{-132.21} \\
\hline
\end{tabular}

Source: SOEP v31 linked with regional data on the county-level (2006-2014). 